Проф. др Јеленка Пандуревић

Универзитет у Бањој Луци

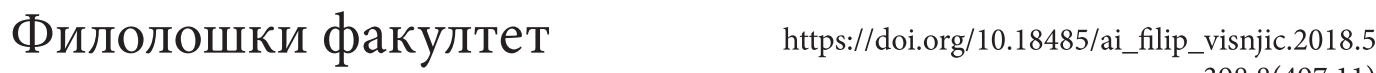

jelenka.pandurevic@flf.unibl.rs $\quad$ 821.163.41.09-13:398 Вишњьић $\Phi$.

\title{
ВИШЊИЋЕВА ЕПСКА ПАРАДИГМА КАО НЕМАТЕРИЈАЛНО КУЛТУРНО НАСЉЕЪЕ
}

У овом раду разматрају се разлози, могућности и ограничења да се јуначка епика и пјевање уз гусле у складу са Унесковом Конвенцијом о заштити нематеријалног културног насљеђа из 2003. године разумију као локална и као национална традиција. Актуелност теме у вези је са чињеницом да је овај елемент, присутан у регистрима Републике Србије као и Републике Српске, нужно сагледан као „жива“ традиција коју заједнице и појединци признају и преносе као израз свог културног насљеђа, одржавајући, према Унесковој дефиницији, „осјећај идентитета и континуитета“. Вищъићева епска парадигма је израз који се у овом раду користи како би се указало не толико на спорадичну неприхватљивост административних рјешења која инистирају на бризи и очувању културног насљеђа искључиво унутар савремених државних граница колико на неискориштене могућности у погледу заједничких номинација за Листу репрезентативног нематеријалног културног насљеђа човјечанства, што су модели које Унеско, заправо, промовише и подржава.

Кључне ријечи: Филип Вишњић, јуначка епика, пјевање уз гусле, нематеријално културно насљеђе, Унеско, номинације елемената.

Брига за културно насљеђе је активност са предумишљајем, која се у процесу који започиње усвајањем 
и имплементацијом Унескове конвенције из 2003. године стратешки усмјерава и испољава у три основна правца: у смислу мапирања и одржавања колективних идентитета, на плану културне дипломатије, те на пољу самоодрживог развоја и економског просперитета заједница и појединаца који су његови носиоци (Краус 2011: 10-14). Документовано и промовисано у збиркама и списима Вука Стефановића Караџића, пјевачко и пјесничко умијеће Филипа Вишњића је, стицајем срећних и несрећних околности, функционисало на све три равни. Вишњићева вјештина и знање условљени су традицијом, а лична креативност која на насљеђеним обрасцима изнова ствара (Кнежевић 2012), била је његов једини капитал. Држава у настајању није могла да му пружи институционалну подршку, али Вук Караџић као најзначајнији посленик на пољу културне политике свакако јесте. У идејном и културном амбијенту који су креирали „пробуђени народи“ предреволуционарне Европе постојале су несумњиве претпоставке за афирмацију његовог стваралаштва у контексту Вуковог пројекта Српских народних пјесама, а у циљу промовисања ослободилачке борбе српског народа, његове историје и народне културе. Да је у његовом времену постојала идејна и административна концепција „идентитетског мапирања“ и „одрживог развоја“ која повезује националне интересе, локалну заједницу и појединца, Филип Вишњић би, као „живо људско насљеђе“, вјероватно испуњавао услове за номинацију.

„Живо људско насљеђе“ је само један у низу Унескових програмских покушаја да заштити и промовише нематеријално културно насљеђе човјечанства, који су своју коначну форму добили у Конвениији о очувану и заштити нематеријалног културног настеђа из 2003. године (Медар Тањга, и др. 2017: 23-35). Од вре- 
мена конструисања националне идентитетске матрице, до времена када „европске вриједности“ добијају повлаштено, па и неприкосновено мјесто у културним политикама, однос према јуначкој епици и пјевању уз гусле мијењао је и интензитет, и предзнак (Пандуревић 2015: 327-347). Како усмене традиције и историјске конструкције неизбјежно имају извјесну дозу искључивости, и трају наспрам прокламованих вриједности које налажу толеранцију и компромис, у овом домену се откривају извјесни парадокси и неуралгичне тачке Унесковог концепта ${ }^{1}$, будући да највећи проблем у вези са импементацијом ове Конвенције заправо и јесу „националне идеологије у ери глобалних фузија“ (Tsitsishvili 2013: 204-232). Јавна дебата у вези са овим пројектом у највећој мјери је и усмјерена на друштвене, идеолошке и политичке механизме који се налазе дубоко у позадини бриге за локалне идентитете, рањиве структуре, мале и маргиналне заједнице. Унеско, наиме, признаје да не само феномен нетолеранције него и процеси глобализације, односно социјалне трансформације, који стварају услове за обновљени дијалог међу заједницама, такође дају основ и подстицај разним процесима погоршања, нестанка и деструкције нематеријалног културног насљеђа. Разматрајући јуначку епику као живо льудско настеђе, Лидија Делић наглашава управо

1 Осјетљивост овог домена и потенцијалне контроверзе наглашене су у предавању које је одржао један од приређивача текста Конвенције, др Рикс Сметс, на тему The domain of oral traditions and expressions, including language as a vehicle of intangible cultural heritage (ICH), as presented and treated under Unesco's ICH Convention („Како се област усмених традиција и израза, укључујући језик као носилац нематеријалног културног наслеђа (НКН) представља и третира у УНЕСКО-вој Конвенцији о очувању нематеријалног културног наслеђа“). Предавање је одржано 12. новембра 2013. године у Етнографском музеју у Београду. 
проблем селективности и компромиса који мора да рачуна са императивом „политичке коректности“:

Конвенцијом се узима у обзир само оно нематеријално наслеђе које је „у складу са важећим међународним правним инструментима као и са потребом узајамног поштована заједница, група и појединаца, али и одрживог развоја“. Тиме се дисквалификују они сегменти националних баштина који, успостављајући историјску перспективу (а она по правилу у мањој или већој мери изневјерава или селективно захвата историјску фактографију) и градећи идентитет заједнице на отклону према историјском (конфесионалном, етничком) Другом (за шта је еклатантан пример јуначка епика) - не задовољавају савремене стандарде „узајамног поштоваға заједнииа, група и појединаца“. (Делић 2017: 48)

Канонски статус Вукове збирке успоставио је јединствену и неупитну идеолошку матрицу, на основу које се јуначка епика и разумије као насљеђе српске књижевности и културе. Савремена гусларска пракса, о којој једино и може бити ријечи у контексту Унескове парадигме, указује, међутим, на важност локалних заједница, као и на „раслојеност привидно кохерентних група“, наглашавајући „проблем репрезентативности слојева традиције и конфронтације у националним оквирима“ (Делић 2017: 52). С тим у вези, Смиљана Ђорђевић покреће веома важна питања у вези са неусаглашеним политичким и идеолошким ставовима различитих група које претендују на статус носилаца традиције:

„Увођење фигура из савременог политичког живота у епски текст подразумева и значајније присуство идеолошко-политичких коментара. С тим у 
вези намеће се низ питања: колико се овакви текстови могу посматрати као 'својина свих' (како се некада жели приказати), у којој је мери креирана слика условљена индивидуалним афинитетима и оријентацијом аутора и извођача (и групе која текст прихвата), те у којој мери епска традиција (и традиција певања уз гусле) на овај начин учествује у процесу 'измишљања традиције' (Hobsbom, Rejndžer 2002).“

(Đorđević Belić 2016: 118)

Односно, у којој мјери су националне јавне политике у области културе спремне да прихвате и безрезервно подрже ставове и вриједности локалних заједница.

Поводом Филипа Вишњића, који има своје постојано мјесто у процесу меморијалне праксе, односно националне културе памћења, могуће је, али и неопходно говорити о имплементацији Конвенције Унеско 2003, коју су ратификовеле и Србија, и Босна и Херцеговина, преузевши обавезе на националном и међународном плану. Ову тему није иницирала само Вишњићева годишњица (1767 - 2017) и биографија расута „измећ' Босне и измеђ’ Србије“ него и медијски дискурс који се успоставља у вези са евентуалном номинацијом Пјевана уз гусле за престижну Репрезентативну листу нематеријалног културног наслеђа човјечанства . Уз начелна питања која се односе на јуначку епику као жанр, и проблем њеног промовисања у контексту политичких инструмената заснованих на „толеранцији“, „људским правима“ и „правима мањина“ (који су уо-

2 Који се у овом тренутку ипак заснива на аналогији са крсном славом која је пред међународном заједницом, уписом на Листу репрезентативног нематеријалног културног насљеђа човјечанства, представљена као културно добро Републике Србије. 
сталом и налагали помјерање акцента са njecмe на njeване), остаје и проблем кандидатуре, односно покретања и одржавања административног механизма којим се промовише и одржава „национално благо“.

У наставку овога рада слиједе транскрипти разговора са гусларима у Требињу'ㅡㄴ као допринос успостављању комплексне визуре, и даљем проблематизовању претходно назначених аспеката.

J: Значи, ми смо данас у Требињу, 7. августа 2016. године. Павле Паовица, Марко Бутурлија ${ }^{4}$ и Јеленка Пандуревић. Марко, хоћете ли се представити и рећи да сте упознати са разлогом нашег данашњег разгово-

3 Интервју са Марком Бутурлијом, младим гусларом из Требиња, рађен је за потребе научноистраживачког пројекта „Проучавање и заштита нематеријалног културног насљеђа Републике Српске“, који је реализован на Филолошком факултету Универзитета у Бањој Луци, уз финансијску подршку Министарства науке и технологије Републике Српске. Теренским истраживањима повремено су присуствовали и студенти, у циљу савладавања основа методологије квалитативних теренских истраживања. Павле Паовица је студент прве године студијског програма етномузикологије на Академији умјетности Универзитета у Бањој Луци и присуствује овом разговору у оквиру теренске праксе. Снимак овог разговора чува се у Дигиталном архиву Филолошког факултета, а копија у Архиву Катедре за етномузикологију Академије умјетности у Бањој Луци. Транскрипт је урадио Павле Паовица, поштујући исказ учесника у разговору упркос мјестимичним огрјешењима о правописну норму.

4 У договору са саговорником, објављују се лични подаци, уз напомену да је тиме изневјерена пракса поштовања анонимности учесника у истраживању, прописана Одлуком о кориштењу Дигиталног архива Филолошког факултета и Кодексом професионалне етике Универзитета у Бањој Луци. Процјена је да је ова врста истраживања афирмативна за учеснике и њихов статус у заједници, као и да би игнорисање личних података заправо означило некоректан став истраживача према њиховом знању, мишљењу и увидима. 
pa, и нагласити да сте сагласни са тим да снимимо овај разговор. Павле би требало да искористи ове податке за свој семинарски рад, а ја и друге колеге, евентуално, за писање неких научних радова.

M: Ја сам Марко Бутулија, поријеклом сам из Требиња, имам 24 године, бавим се гусларством од своје четврте године. Упознат сам са сврхом овог разговора и са свим тим што сте Ви рекли.

J: Добро. Шта значи бавити се гусларством од четврте године?

M: Па, за мене, бавити се гусларством значи много више од обичног свирања иструмента, јер моје бављење гусларством је дубоко везано са мојим коријенима, с тим да је мој деда покојни, мој прадеда покојни, сви у породици, да су сви били гуслари и да су се сви бавили гусларством, да је то у мојој кући нека традиција преношена с кољена на кољено и ја то за себе сматрам неком обавезом према својим коријенима.

J: А какви су утисци из дјетињства? Када се гуслање практиковало, у којим ситуацијама, да ли су неке посебне прилике биле резервисане за то или је то била свакодневница? Да ли је постојао неки устаљени ред и систем правила када, ко , гдје, како узима инструмент и гусла или је то била просто нека врста, хајде да кажемо, разоноде, разбрибриге, кориштење слободног времена?

M: Ја бих Вама могао испричати једну врло занимљиву причу. Иначе, гусле су мени урезане у генима зато што ја сам рођен '92. године, мој деда је умро '89. године, звао се Марко исто. Он је знао да гусла, мој отац није знао да гусла, његов покојни брат је знао да гусла али је погино '79. године. И тада '79. године када је погино, мој покојни деда Марко, који се звао исто као ја, узео је породичне гусле које је он сам себи направио и у том неком свом јаду и несрећи која их је задесила он је на 
тим гуслама хтио да искали сав бијес, јер су оне биле дио његовог живота, да каже да никад нико у тој кући неће да загусла, да нико никад више неће узети тај инструмент, запјевати, јер је то опет једна велика несрећа за породицу била, и тада је моја баба, која је данас жива, узела од дједа те гусле и рекла: „Нека, Марко, можда ће ти унук гуслат“. И ето, још десет година је деда живио, '89. године је умро, '92. године родио сам се ја, '96. године први пут у животу сам видио гусле. И то је био, сад већ долазим на оно што сте ме питали, то је био Бадњи дан када се код нас у Херцеговини, углавном и у осталим мјестима, припрема пецивица за Божић. То је било негдје после рата '96. године, ја сам имао 4 године. Дедин можда један од најбољих пријатеља у животу је био гуслар и он је био ту код нас у кући, било је доста народа који су код нас окретали пецивицу на ражњу. Неко је рекао да би волио да чује како се гусла, јер код нас је то у Херцеговини обичај, да се за такве прилике гусла, и донијели су гусле од једног комшије. И ја сам тада први пут видио гусле. У мени је тада, једноставно могу рећи, прорадио неки ген, никада више се нисам растао од гусала.

J: А можемо ли се вратити на те неке приче из дјетињства. Кажете, Марко, да је дјед сам направио гусле, да је он био гуслар и да вам је стриц био гуслар, а отац није. Можемо ли на томе да се задржимо? Када је дјед, како је направио гусле, вјероватно је постојала нека прича о томе, како су изгледалате гусле, да ли постоји неки одређен начин како су се оне правиле, како су изгледале и да ли су биле другачије од ових које данас које се данас праве? Да причамо о том породичном сјећању на дједа и његов репертоар, и прилике у којима је он гуслао.

M: Па, већ сам вам рекао, деда је умро '89., ја сам се родио '92., али доста тога хвала Богу баба ми је жива, испричала доста тога што се деде тиче. Деда је иначе 
био полицајац, радио је ту у служби у Требињу. То је вријеме било јако тешко за одржати, да гусле живе у том времену, јер је то вријеме било ипак вријеме комунизма, гдје се није могло јасно и гласно изражавати нека српска историја кроз те гусле. Међутим, деда је од малена, уз свог оца и свог деду научио да гусла и некада шездесетих година, ја тачно не знам датум, наручио је гусле од једног мајстора из Требиња, не знам ни његово име, мада, можда бих могао да се распитам. Те гусле не могу да се пореде са данашњим начином прављења гусала. Те гусле су сасвим нормално израђене, без неких украса. Нису тачно израђене, мало су криве, криво им је држало гдје се држи, крива им је карлица доле на којој је кожа. Можда, што јест јест, видио сам у животу доста примјерака гусала, али дедине гусле су онако оригиналне. Оне горе имају као плочу гдје је украс и ту је његова слика из младости. Дан данас ја имам те гусле.

J: А да ли им је величина, облик, димензије, да ли су другачије?

M: Не, не. Облик и димензије, све, дужина, величина све то је потпуно исто, отприлике. Само зависи од мајстора до мајстора. Најбољи мајстор који је икада правио гусле, што се у круговима гуслара прича и зна, најбољи је Драго Кубуровић и та његова израда гусала је доведена до савршенства. То су гусле које сте вјероватно гледали, са украсом Св. Георгија кад убија аждају.

$\mathrm{J}$ : То је заштитни знак његове радионице?

M: Јесте, правио је он и гусле са украсом козије главе, али јако мало примјерака има. То су значи гусле које су тренутно на тржишту најскупље и убједљиво су најквалитетније. Кажем Вам, зависи од мајстора до мајстора и неке маштовитости тих мајстора шта могу и како могу да израде. Те гусле се не разликују ни по чему од дединих гусала. Данашње гусле су задржале основ- 
ни облик тих неких старинских гусала. То су јако мале неке измјене што се тиче украса, дужине. Неки гуслари праве мало дуже гусле, неки мало краће.

J: Да ли је материјал за израду увијек исти?

M: Па знате како, доста мајстора је још остало при том неком старом народном предању: „гусле јаворове“. Доста мајстора за гусле прави баш те, јаворове гусле. Мада, ево на примјер, моје гусле су од сувог ораха и има доста примјера којих сам гледао, на стотине таквих гусала. Могу Вам рећи да су боље од јаворових и имају бољи звук, и много су лакше за држати, јавор је много тежак, орах је много лакши и много је лакше баратати са њим.

J: Шта мислите, зашто је тај јавор уопште потенциран?

M: Па вјероватно, по мом неком скромном мишљењу, ја сам прве гусле које сам у животу имао, то су биле јаворове гусле. Јер тада, причао сам Вам, са 4 године када сам први пут видио гусле, гусле су биле од мог рођака, комшије. Већ сам Вам рекао да је деда те своје гусле, када му је син погинуо, покидао струну са њих, тако да оне нису биле функционалне и пошто су морали том рођаку да врате гусле, тада је мој отац са пријатељем дединим ишао у шуму, убрао јавор и од јавора су ми онда направили мале гуслице, које су биле онако прилагођене мом узрасту. Ипак, ја сам имао четири године. Мислим да је јавор у суштини, по мом неком мишљењу, најквалитетније дрво и да се са њим најлакше може радити, ти мајстори најлакше раде са јавором.

$\mathrm{J}:$ Да ли се још нешто израђује од јаворовог дрвета у домаћинству, за употребу, да ли имате неко искуство?

M: Ја углавном не знам, можда су се некада прије израђивали самари, шта знам, тако те неке ствари што су биле потребне људима за земљорадњу, али иначе не знам.

J: Не постоји нешто посебно у кућанству, што се 
искључиво прави од јаворовог дрвета?

M: Не знам, можда једино иконе, знам да иконе праве фрескописци.

J: Добро. Значи, може да се прави од ораховине, од чега још?

M: Ја да знам, од јавора и од ораха. Мада, ето, ја нисам пуно упознат са начином прављења, мада знам доста мајстора. У суштини, мислим да је данас та техника и ти мајстори да су себе максимално унаприједили, да могу од разноразних врста дрвета да направе гусле, мада, кажем Вам, најквалитетније су од јавора и убједљиво од ораха.

J: А струне?

M: Сасвим је нормално да се за струну ставља и на гудало и на гусле силк, рибарски силк. И те гусле сасвим нормално звуче. Док, прије је био обичај да се струна прави од коњског репа. Коњски реп је стављан и на гудало и на гусле. После тога су гуслари, док се то мало није измијенило, стављали су или на гусле или на гудало бар негдје да буде коњски реп, а ово остало је могло бити од рибарског силка. Моје гусле, на којим се ја такмичим, које свугдје носим, су од рибарског силка и нема неке велике разлике. Чак ја мислим да је много бољи звук, јер коњска длака, ја сам имао гусле са коњском длаком. Коњска длака се брзо запрља, прашину покупи, замасти се, јако је тешко њу опрати и очистити. Много је танка, она брзо пуца, тако да требало би се онда много често мијењати. Треба одређен број струна, намотаја да буде на гуслама и одређен број намотаја на гудалу.

J: Рекли сте да је дјед наручио гусле за себе, за своју кућу, за своју употребу. Од тада постоји породична традиција и те исте гусле се сада могу наћи у рукама његових насљедника. Да ли постоји неко правило када је у питању насљеђивање инструмента? Ево, рецимо, 
имао је два сина или више... Како то иде?

M: Знате како, да постоји неко правило, не постоји. Али, код нас, у менталитету једног Херцеговца је да ми иначе гајимо велико поштовање према својим коријенима. Те гусле су за мене... не знам како бих Вам описао...те гусле су непроцјењиве вриједности. Једноставно, те гусле значе мени... То је једна успомена на мог покојног дједа.

J: Да је дјед имао више унука, или више синова, како би одлучио коме од њих ће оставити?

M: Гусле нису нешто што се оставља једној личности. Гусле су иначе у свакој кући у Херцеговини, у 90\% кућа, кад уђете имате гусле које висе у кући.

J: Гдје висе?

M: Увијек поред иконе, или су поред кандила, значи увијек централно мјесто у кући оне заузимају. То су гусле једне породице, која ту живи. Оне не припадају једном члану, него једној породици.

J: А када се скидају са тог мјеста, у којим ситуацијама?

M: Па, углавном када су славе, када је Божић, када прослављамо неке наше вјерске празнике, када имамо разлог за неко весеље.

J: Који су то разлози, конкретно?

М: Можда рођење дјетета у тој кући, слава, Божић, вјероватно неки гости који су ту дошли, ако неко жели да чује, ако неко зна у тој кући да загусла. Ја доста пута када ми дођу мала дјеца у кућу, дјеца од неких пријатеља, узмем гусле, гуслам им и показујем им како то звучи, јер је њима то занимљиво.

J: А да ли оно што се изводи зависи од ситуације до ситуације?

М: Зависи.

J: Пошто је тај инструмент смјештен уз иконе и 
прати тај неки круг празничних догађаја, или како сте рекли, весеља, ситуација које подразумјевају породично окупљање, како се прилагођава репертоар за сваки поједини догађај?

M: Па ево могу Вам баш сада навести примјер. Посљедњи пут када сам имао неки јавни наступ, било је то на свадби моје сестре. Моја сестра ради у Мостару и, наравно, дошле су колеге са посла различите вјероисповијести и националности. Неки су муслимани, неки су католици и ту је јако тешко изабрати, ако већ хоћеш да представиш свој инструмент и... ако хоћеш да на свадби, то је ипак породична манифестација. Ако хоћеш да узмеш тај породични инструмент и да поздравиш све људе, јако је тешко изабрати репертоар. Ја сам отприлике онако написао неке стихове које сам за ту прилику отпјевао. Једноставно, да не бих увриједио неког нечим, да се ти људи не би осјећали увријеђено, да не припадају ту.

J: Мало бих се задржала код овога. Зашто би се слушаоци друге националности односно вјероисповијести могли осјећати нелагодно у позицији слушаоца? Зашто? Да ли Ви мислите да они немају такво искуство у свом некаквом окужењу? Мислим на гуслање и гусларе.

М: Мислим да имају. Свако од њих. И Хрвати имају своје гусле, организују такмичења.

$\mathrm{J}:$ Мислите ли да имају муслимани?

M: Па врло је могуће да имају. Имају неки сличан инструмент, иначе ја сам онако отприлике, што сам чуо и што сам истраживао. Ја сам чуо да су гусле потекле из Азије, да је то један инструмент који је сличан гуслама. Има једну струну, гудало, којим се превлачи, да смо ми то преузели давно некада. Ти стихови, иначе гусле, пјевају о српској историји и доста тога сто памтимо из 
историје опјевано је на гуслама, та нека дешавања.

J: А мислите да други народи немају те исте приче, које пјевају уз гусле?

М: Мислим да имају. На овим просторима, послије посљедњег рата, гусле су значиле неки српски инструмент, неки позив у бој, неко охрабривање војника. Тако да мислим да би сада, у овом времену, гуслање неких стихова и неких пјесама увриједило људе друге националности. Тако да мислим да у одређеној прилици треба имати неки репертоар који је погодан за ту прилику. Када се деси нека екипа која је млађа. Жене ту и тамо мање воле гусле од мушкараца.

J: Зашто је то тако?

M: Немам сада искуства толико. Има жена које воле гусле, али једноставно, гусле су мушки инструмент и оне пјевају о јунаштву, херојству, историји и то је некако више везано за карактер мушкарца.

J: Нема жена гуслара?

М: Има. Била је прије једна жена из Црне Горе, Мила Котлаја, чини ми се. Има сада Бојана Пековић која гусла. По мени је то више за мушкарце.

J: Постоји ли неки репертоар за жене, да ли се, ако круг слушалаца чине и жене, да ли се тај репертоар прилагођава? Да ли постоје неке теме које су искључиво резервисане за мушкарце, или које чак није упутно изводити у мјешовитом или женском друштву?

М: Ја сам имао више тих неких сцена са гуслама, и управо са том ситуацијом гдје су више жене гусларска публика. Ја сам био на једној свадби у Требињу. Видио сам да је ту углавном женско друштво и пјевао сам пјесму Јелена, кад Књаз Никола удаје ћерку Јелену. То је једна пјесма, која је лагана за слушати, у којој се не прича о биткама, о јунаштву, него се прича о једној, може се рећи, о тужној судбини једне принцезе у Црној Гори, 
коју је отац удао за принца Италије ради добрих односа Црне Горе и Италије, што се дешавало у нашој историји. Она је била заљубљена у његовог дворјаника. То су некакве теме које жене могу да слушају, и мислим да је пожељно, када се нађете у таквом друштву, изабрати такву пјесму да би жене могле да слушају, да се не би осјећале ту као да не припадају, да би њихову пажњу могли да заокупите том пјесмом. Има још једна дивна пјесма, „Стојан и Љиљана“, то је писао наш гуслар из Црне Горе, Рајо Војиновић. Ту је исто једна тема у којој је момак отишао у хајдуке. Он се враћа из планине, затиче ту своју другарицу, пријатељицу, шта му је већ била, дјевојка, како чува овце. Они се радују састанку. Док послије тога, дан - два, пјесма каже: „Стина киша лину, гледа млада цура уз планину, па јој срце вене тога дана, нема њојзи на извор Јована“. Он је отишао у хајдуке, опет у неку битку. Ту је убијен и она њега налази у тој шуми и умире над његовим тијелом и она. То су неке теме које жене воле и могу да слушају. Свадбе и славе, то су неке ситуације у којима не морате да пјевате јуначке пјесме. У ствари, није ни пожељно да пјевате јуначке пјесме. То је једна лагана атмосфера, ту можете да пјевате народне неке старе пјесме, које је Вук записивао.

J: Да ли су гусле и гуслари искључиво везани за празнике, односно за те, како сте рекли, тренутке везане за весеље у породицама, да ли се гусла приликом смрти у породици, или приликом помена?

М: Па у Херцеговини не, мада сам чуо да има доста примјера у Црној Гори. Мада, кажем Вам, када сам почео да гуслам, ишао сам у ту неку школу гусала. И ту је био један старији гуслар, Митар Ђого, који је држао ту школу. Видите, гуслати је јако тешко научити. Ја мислим да за то морате имати дар неки, немате неки шаблон по коме се учи, гусле се не записују нотама, то 
је све до слуха, талента, гена, што вам Бог да. Тај гуслар, он је доста стар, сада има 80 год, ја се са њим понекад и видим. Он мени увијек каже: „Ја кад умрем, Ви ћете ми на гробу гуслати“. Имате људи који изразе такву жељу, мада ја још нисам чуо да је то неко у Херцеговини то урадио. Али ја вјерујем да је он такав, он стварно гусле воли, обожава. У неко тешко вријеме, кад је било тешко гусле одржати, чувати их, кад су се гусле скривале, он је био тај који је увијек гусле преносио.

$\mathrm{J}$ : Хајде да се мало задржимо код те школе гусала. Појам школе се обично везује за неку врсту професионалног усмјеравања, или образовања за неки професионални ангажман. Да ли је та школа гусала имала такву сврху и такву намјену? Односно, да ли постоји простор гусларске професије?

M: Гусле нису нешто чиме се човјек може професионално бавити, по мом мишљењу. Али имате доста гуслара који се тиме баве и хране своју породицу. Нпр. Ђоко Копривица, Миломир Миљанић, Саша Лакетић, Бошко Вујачић, Бранко Перовић. То су људи који су радили са стране, имали посао, али су успјели да на неким својим концертима зараде, да допринесу неком свом буџету. Мислим да у суштини то не би требало да буде професија, ако већ није нека професија, ако није то потребно, јер мислим да гусле онда губе неку своју чар. Ви онда морате да снимате, да пјевате и оно што у ствари гусле нису, да забављате народ, да то буде интересантно народу.

J: Да ли је онда можда, ево у Вашем случају, гусларство хоби?

М: У мом јесте. Хоби и традиција, рекао сам Вам на почетку, то је нешто што је једноставно мени урезано, што тече мојим венама, ја никад не бих могао оставити гусле, ја никада нећу престати у животу 
гуслати. Ако Бог да, када будем имао своју породицу, учићу своју дјецу да воле гусле. Бићу најсрећнији ако ми дијете буде гуслар.

J: А говорили сте и о том удружењу гусларском. Како оно функционише, односно који се тип гуслара окупља, какве циљеве има, како функционише, какве активности има?

M: У Требињу имају два гусларска друштва: Војвода Лука Вукаловић и Недељко Видаковић. То је једно удружење у којему се окупљају људи који воле гусле, првенствено људи који воле гусле, после тога гуслари који су чланови тог удружења и који се на нивоу Савеза такмиче. Морате бити члан неког гусларског друштва, да би се такмичили. У нашем друштву има доста људи који нису гуслари, који једноставно воле то, и они имају нека задужења. Да они нама изнађу неке финансије, које нам требају за такмичења, да организујемо неки концерт, да промовишу гусле. Имате гусларе који боље баратају гуслама и који слабије баратају гуслама. То је углавном све исто, гуслар је гуслар и сваки гуслар је по себи специфичан. Ја још нисам чуо гуслара који гусла као неки други гуслар. Док имате пјевача који пјева као неки други пјевач. Имате многе композиције које је написао Моцарт, Бах, па данас изводе дјеца у музичкој школи. То у гуслама нема. Сваки гуслар је специфичан сам по себи.

J: Који су то елементи који разликују извођење једног гуслара од другог гуслара?

М: Па, елементи... Причали смо о том како имају различите гусле, гусле различите боје звука, гуслари се разликују по боји гласа. Неки пјевају високо, зависи од тоналитета који гуслар може да отпјева, да изнесе. Највише тога зависи од начина казивања пјесме. Гуслари различито казују пјесму, у зависности како они могу 
да изведу ту пјесму. Гуслање њихово само на гуслама, без пјевања, зависи, значи, да ли неко добро удара прстима, то се каже „удара прстима“. Постоји низ неких цака које утичу на то да гусле буду специфичне и код сваког различите.

J: Значи, то је ствар укуса, како неко гусла?

М: Да, то је ствар укуса.

J: А оно што мене сада као лаика потпуно збуњује, на ком нивоу се онда организују такмичења? Који се параметри могу узимати, ако је све ствар укуса? Које мјерило имате да прогласите, у низу гуслара, некога ко је бољи, мало бољи, мало лошији, први, други, седамнаести, ако је то потпуно лична импресија и доживљај онога који слуша.

М: Па видите, то ни данас није тачно утврђено. Савези и људи који организују фестивале труде се да се отприлике неки шаблон направи по коме ће се моћи оцјењивати гуслари. Једноставно, све зависи од укуса слушалаца, а жири и они који оцјењују то углавном су људи који су успјешни били у гусларству, који се више не такмиче, који су доста гуслара послушали у животу и који могу отприлике да знају шта је ту добро, а шта лоше. Људи који су, ево на примјер професор Љубо који је професор народне књижевности из Бањалуке. Он је сваке године у жирију на нивоу Републике Српске. Онда професор Љубомир Зуковић, он је академик, то су људи који су људи који су успјешни у некој сфери музике, књижевности, историје, етномузикологије, који могу то да оцијене отприлике. Могу да виде како то звучи и да ли је гуслар ту своју пјесму изнио онако да би ви могли ту пјесму да доживите.

J: Опет се сада враћамо на ону ствар укуса и личног доживљаја. Ево, да поједноставим питање, шта то значи бити успјешан гуслар? Шта је то, ако сте рекли 
да је гуслање лични израз, шта је то што некога чини успјешнијим?

M: То да ли је он успјешан гуслар значи, да ли ће се он допасти некој широј маси, његов стил гуслања. То су људи који су неких тридесет-четрдесет година живјели са тим гуслама и народ их је волио слушати. Док имате гусларе који имају опет неки свој стил, али се то не свиђа народу и некој широј маси. По томе је направљен тај шаблон.

J: А да ли смо се сада нашли на тачки којом смо започели ову тему, да ли су онда професионални и успјешни гуслари једно те исто?

М: Јесте, да.

J: Значи, та гусларска такмичења су једна врста професионалног одмјеравања?

M: Па јесу.

J: Малоприје сте ми рекли да бити професионални гуслар значи правити компромис са укусом публике, да би сте могли да продате плочу, концерт, значи ви правите компромис са њима. Између оног како би сте ви вољели и жељели и оног што се од вас тражи. Да ли је то исто онда када су у питању гусларска такмичења?

М: Јесте, Ви сте у праву ту сто посто. Само, знате шта је ту велика разлика, што се на тим фестивалима појави велики број гуслара, а имате седам-осам гуслара који се ту врте увијек и котирају високо. Њихов стил и њихов начин пјевања је увијек најбоље оцјењен. Ево на примјер, ја се такмичим, али се не бавим професионалним гуслањем. Да се бавим професионално гуслама, да зарађујем на гуслама, да снимам плоче. Имам снимљену једну касету и један ЦД, али то није за продају и није за комерцијалу. То је, једноставно, нешто што имам ја, док имате гусларе који раде, пјевају и такмиче се да би могли да продају касету и да би били позвани негдје да зараде. 
J: Али, сви се такмиче са намјером да остваре што бољи резултат.

M: Такмиче се и са том жељом, али моје мишљење је да доста тих гуслара дође ту да би било присутно, јер воле гусле. Није ту много изражен тај такмичарски неки набој. Изражен је, да кажем, код тих десет-петнаест људи који високо котирају, а остали су ту да би слушали, да би доживјели то, да би једноставно учествовали на тој манифестацији.

J: Како се припремате за та такмичења, односно које су то пропозиције? О којим елементима се води рачуна - прво, да би се уопште задовољили критеријуми да будете учесник у такмичењу, а друго да би остварили што бољи резултат?

M: Па постоје пропозиције, углавном, по којима се пријављујеш на фестивал. Постоји значи, прије док је била Југославија, било је само једно такмичење на нивоу државе. Сада, пошто имамо три српске земље, Република Српска, Србија и Црна Гора, постоје три савеза. Сваки је посебно, савез РС, савез Србије и савез Црне Горе, који организују такмичења на нивоу тих држава. На тим такмичењима учествују удружења која су чланови тог савеза. Имате кровни савез који је савез који окупља сва три савеза, то је савез српских гуслара. Имате такмичење једно на нивоу тог кровног савеза на које пролазе најбоље пласирани на републичким фестивалима. Е сада када су у питању пропозиције, оне су исте за савезни фестивал и за републичке фестивале. За републички фестивал, он се сваке године одржава у другом граду, то је по мом мишљењу најбоље због промоције гусала, пријављују се пјесме у полуфиналу. Мјесец дана прије тога, пријављују се пјесме савезу које ћете да пјевате на том фестивалу. Имате полуфинале, фестивал траје двије ноћи, полуфинале и финале. По- 
требно је да буде једна народна, неримована пјесма и друга пјесма по избору. Може од ових нових текстописаца, људи који пишу пјесме. У полуфиналу се пјева двадесет до тридесет стихова и пјевате онако како сте написали, сваки стих онако како сте написали, јер има техничка комисија која прати то. Ако погријешите, добијате казнене бодове. Фестивал почиње аудицијом, на аудицију иду сви гуслари који су се пријавили. Она је углавном на дан полуфинала, али буде ујутру. На тој аудицији се пјева пет до шест стихова, на којима жири процјењује то да ли ви имате квалитет да наступите у полуфиналу. У полуфиналу учествује четрдесет гуслара, и у полуфиналу од четрдесет најбољих бира се двадесет најбољих и у финалу се бира наравно првак, други, трећи. Оцјењује се првих десет са републичког фестивала који иду на савезни фестивал који буде некад зими, или на јесен. Тај савезни фестивал се увијек одржава у једној од те три земље, ево на примјер ове године је био у Никшићу. На савезном фестивалу немате аудицију, имате четрдесет најбољих гуслара, значи десет из сваког савеза, и десет оних који су прошле године били међу првих десет на том савезном фестивалу.

$\mathrm{J}:$ То је значи неки формални систем учествовања на фестивалу. А ово што сте рекли ми је, као лаику, веома интересантно... Значи, унапријед напишете стихове које ћете изводити, а жири прати да ли сте одступили?

M: Не, жири оцјењује, има техничка комисија која то прати, па касније каже жирију да нам одузму бодове.

J: Што значи да је један од врхунских квалитета код гуслара способност меморије, односно памћење.

M: Јесте.

J: Значи, не вреднује се способност импровизације, да ви сад у тренутку надахнућа склопите те стихо- 
ве... Односно, свако извођење неке пјесме треба да буде идентично.

M: Постоје ту нека мала одступања од тих правила, знате како. Ако сте ви написали нешто, неких двадесет-тридесет стихова, а можда сте погријешили неку ријеч или тако нешто, онда вам неће ту одузети бод.

J: Али ви, значи, не можете бити понесени тим својим извођењем, па тог момента креирати неку...?

M: Па можете, али ту се највише кажњава ако гуслар, оно што је пријавио, ако прескочи тај дио. То су углавном одломци који су везани. Не можете испрескакати пјесму, пјевати првих пет стихова, па сто педесети, знате. Мора бити једна цјелина. Ако је гуслар испрескакао те стихове, и ако та пјесма на крају нема неку поруку... Или, на примјер, дешавало се да људи у једној пјесми пјевају двије или три пјесме. Забораве стихове, па пјевају стихове неке друге која није везана за то што су пријавили. Е, тад се кажњава, а ако се као што кажете у тренутку надахнућа погријеши нека ријеч или замјените редосљед ријечи, а то испадне океј, неће вам нико то узети за зло.

J: А те пјесме које се пријављују... Ево, које се пјесме могу пријавити? Какво је поријекло пјесама које се пјевају?

M: Па кажем вам, није одређено, али у полуфиналу и финалу мора бити једна народна пјесма.

J: Шта значи народна пјесма?

M: То су ове неримоване епске пјесме које Вук записивао, које је прикупљао Тешан Подруговић, које је пјевао Филип Вишњић. Ево, на примјер, ја сам сад на задњем републичком фестивалу пјевао пјесму „Предраг и Ненад“, а имате писце који су касније исто писали, само што су они писали римоване пјесме. Описивали су исте пјесме и исте догађаје само у римованом неком стилу. 


\section{J: Које се више цијене?}

М: Па све зависи, мада народ више воли те римоване, јер су лакше за слушати, а гуслари их више воле јер су лакше за пјевати. Ја на примјер не одвајам, зависи од пјесме до пјесме, али некако те римоване пјесме људи данас више воле. Јер, те римоване пјесме описују новију историју која нема дубок печат, на примјер пјесме о Радовану Караџићу, Ратку Младићу, Дражи Михајловићу, краљу Петру... За ове раније историја није сигурна да ли су они хероји или нису, ипак прошло је много времена да можемо сигурно поредити цара Лазара и Ратка Младића.

J: Значи сваки гуслар пријави одломак из Вукове збирке, из неког класичног корпуса одломак, и пријави шта још?

M: Ја сам слушао доста људи који пјевају пјесме које уопште нису нигдје записане, али се зна да су то неримоване пјесме, постоје људи у жирију који то препознају те пјесме. Рекао сам, професор Љубомир Зуковић, он има ту епску поезију у малом прсту. Зна да је то пјесма која је компетентна за тај вид такмичења. Пријави се одломак, много је тешко да тај одломак од двадесет-тридесет стихова има неку поенту и причу на крају, овај, гуслари одреде отприлике.

J: Колико има стихова та пјесма која има читаву причу обухваћену?

М: Зависи, зависи од пјесме до пјесме. Имате пјесме од петсто стихова, од сто од тридесет, зависи која је пјесма.

\section{$\mathrm{J}:$ А те римоване?}

М: Исто, исто. Ја имам збирке Радована Бећировића, не могу сад свих да се сјетим, ти писци који су писали те пјесме, које су много квалитетне. Можда има много квалитетнијих од народних епских пјесама, али народ их више воли. 
J: Да ли постоји проблем у ауторским правима, кажете да су то пјесме пјесника, па сад наводите ауторе. Да ли је проблем да неки гуслар туђе пјесме изводи, или то мора да нагласи?

М: Није проблем, није.

J: Не постоји никаква формална или неформална обавеза да се то нагласи, пјеваћу пјесму тога и тога?

$\mathrm{M}: \mathrm{He}$, не.

J: А како се онда зна чија је то пјесма, или то уопште није важно?

М: Коме је важно, тај се распита, али то није важно. Данас имате доста пјесника који себе цијене, који пишу пјесме, али гуслар процијени да то није пјесма коју може пјевати. На примјер Радован Требишки, он је по мени најбоље пјесме написао, Божо Ђурановић исто, много фине пјесме пише, и много их гуслара пјева. Али потреба да напишем ко је написао ту пјесму, нема је. Можда на неким концертима водитеља интересује, а иначе уопште није битно. Гуслари између себе наравно, сад не знам... Неко је написао пјесму и дао је мени да је ја снимим, онда гуслари између себе неће рећи, е ја ћу је снимити, нећеш ти. Нема тих проблема никада.

J: Дакле на фестивалима се оцјењује тачност, да ли гуслар тачно отпјевао текстове које је у пријави написао. Значи, није пракса нити се вреднује импровизација, односно његова способност да на лицу мјеста смисли пјесму. То није вредновано. А шта јесте? Ви ме исправите ако нисам у праву, значи, пуно и апсолутно повјерење се даје жирију и његовој компетенцији, и у њихове критеријуме се не улази. Значи, важно је да се допало жирију.

М: Мислим увијек на тим фестивалима постоји... у свлачионицама тамо између нас... између гуслара и људи који су дошли да пропрате... то што смо причали 
малоприје. Имате различите укусе. Неко каже није добро оцијењен, неко је оштећен, неко је прецијењен. Па шта ја знам, постоји ту и доста пристрасности, знате, мислим свако удружење ће више подржат свог неког. Имате неког ко једноставно хоће да подржи свог неког члана, онда добар му је пријатељ, па је он за њега добар гуслар, воли њега једноставно, његов стил, овај други не воли и тако то, али углавном се бира... Значи, кажем вам, то још није дефинитивно. Ја мислим да се то никад неће моћи утврдити шаблон како гуслар мора да гусла. Правила нека да се напишу, како мора да гусла, јер баш зато су гусле и специфичне и инересантне.

J: Кажете свлачионице, није ми јасно то, имате?

М: Па фестивали се одржавају у домовима културе, у спортским дворанама, у позоришним салама и тамо гдје се пресвлачимо, гдје облачимо народне ношње ту будемо сви.

J: То је једно од правила, да наступате у народној ношњи?

M: Јесте.

$\mathrm{J}:$ А да ли је прописан тип народне ношње?

M: Ја наступам у црногорској народној ношњи. У савезу стварно не праве проблем око тога. То су све неке српске ношње. Имате гусларе у Србији, они највише наступају у србијанским ношњама. Црне јелеке имају, бијеле кошуље... Црногорци у црногорским ношњама. Ми одавде, Херцеговци, у црногорским и херцеговачким, зависи ко како.

$\mathrm{J}:$ Која је разлика између црногорске и херцеговачке ношње?

M: Црногорска ношња има... ево ја на примјер не наступам у долами. Имају зелену доламу коју носе као капут, зелени. Овај, разлика је у томе, на примјер, херцеговачка ношња има, мало њих има оне металне токе. Тешке оне токе које су од метала прављене, док, 
то је јако мала разлика, док је црногорска ношња извезена. Она има извезене токе кроз које се не провлачи рукав. Има џамадан без рукава и на њега навлачите токе и провлачите испод. Значи, испод има отвор кроз који провлачите руке. Значи, види вам се, овај, рукави су вам од кошуље а иза вас је као имитација рукава од тока. То је једна од разлика, а ово остало је све исто.

J: А зашто сте онда изабрали црногорску ношњу?

M: Ношње су јако скупе и јако их мало има, знате.

J: Ко их израђује и гдје их набављате?

M: Ја немам, немам своју личну ношњу, удружење има своје те ношње и ми се пресвлачимо кад излазимо.

J: Разумијем. А зашто су скупе, односно ко их изpaђyje?

M: Па зато што се ручно праве, квалитетне су, квалитетан је материјал. Овдје у Требињу, ја да знам, нема људи. Има ту једна жена, али она то не ради све ручно, она не везе. Нешто оно крпи, да то овако изгледа. Али овако су много скупе. Ја мислим, око 2500 КМ ова ношња што ми у друштву имамо.

J: А како превазилазите ситуације када пресвлачите одјећу? Не може сваки гуслар у исте панталоне да стане.

M: Знате како, панталоне су доста широке на народним ношњама и може скоро сваки гуслар да стане. Неко се мало више затегне, неко мање али овај, углавном немамо проблема са тим. Ја сам, на примјер, имао прије, кад сам млађи био, пошто сам ја са четири године почео да гуслам, са пет сам већ почео да наступам, са шест сам се први пут такмичио на омладинском фестивалу и некад можда до десете године, културно умјетничко друштво „Алат“ из Требиња ми је давало ту једну херцеговачку ношњу са металним токама, која је била, овај, мањих димензија и ја док нисам, док сам био 
млађи, носио сам ту ношњу. Кад сам касније прерастао, почео сам да носим црногорску.

J: Да ли је гуслање по вама сеоска или градска традиција?

M: Па сеоска сигурно, али ја се трудим, ево 24 ми је године, трудим се да, да ту не буде нека, да то не буде нешто што је данашња омладина се стиди тога. И ја се трудим да то промовишем на начин да је то нешто сасвим нормално, неко очување наше традиције, да су гусле наш традиционални национални инструмент. Да гусле нису, знате како људи, овај, сматрају некако баш то то сам вам рекао, то је сеоски, сељачки неки израз. То је нешто сасвим нормално исто као што неки народи имају своје националне инструменте, па се уопште не стиде тога. Ми смо некако почели да се стидимо тих гусала.

J: А да ли постоји јавно извођење? Кад кажем јавно мислим на простор изван властита четири зида. Да ли постоји јавно извођење које није оптерећено тим сценским декором? Те свлачионице, народне ношње?

М: Да. На примјер Бошко Вујачић, то је један од можда, можда најбољих најславнијих гуслара, посљедњих можда 50 година. Човјек који доста зна о гуслама и који је у гусларству дуго. Он је баш недавно причао једну, чуо сам, страшну изјаву је дао. Рекао је као: „Гуслари, народни гуслар шта год да носи на себи, он живи у том времену и он гусла“. Данашњу одјећу коју ми носимо, није уопште, знате како. Та такмичења су урађена да би се некако тај изворни дио сачувао, традиција, да се виде те ношње што су некад људи носили. Али гуслар по мени је и онај било какву одјећу да носи, то је опет народна одјећа коју сви ми носимо. Мислим да уопште није на тим јавним наступима потреба некад ни да облачите ношњу.

J: Да ли постоји, односно да ли ви имате то искуство, колико гусле као инструмент, односно тради- 
ционални начин извођења на гуслама, колико ступа у ове савремене комбинације етно фјужна или, не знам, поигравања са етно стиловима? Да ли се комбинује са електронском музиком, да би се добио некакав модерни популарни етно звук? Као што други етно састави раде? Је ли имате нека искуства како они то изводе?

M: Па ја, на примјер, доста сам увјежбао ту неку технику свирања на гуслама. Ја онако могу да изведем неке мелодије које нису етно, које нису епске, могу да изведем на гуслама. Мада не практикујем, то је више овако некад чисто ето, да можда, јавно никад, али овако у друштву некад. Чисто мало да виде људи да се може и то на гуслама.

J: А да ли је то можда некакав пут по вашем мишљењу, и нека врста компромиса са музичким укусима?

М: Ја мислим да је то...

J: Да ли је то начин популаризације, односно превазилажење тог антагонизма, јер, како сте рекли за младе генерације које то не желе, не могу или немају никакав сензибилитет, да ли је то начин?

М: Мислим да јесте, али мислим да је то само, да тим неким извођењем и играњем са гуслама, овај да привучете народ да те гусле мало другачије гледају. А у ствари мислим да гусле никад неће и не би смјеле изгубити свој неки интегритет, оно у ствари што оне јесу.

J: А ја морам да закључим, да ви сматрате да је у питању интегритет гусларске традиције. Да је она некако монолитна, значи, да нема своје фазе или...

M: Да она сад нешто може да напредује, мислим да може, али да не би требала. Овај, мислим да тај звук гусала може се искористити у овој савременој музици у неке сврхе. На примјер, Ђоко Копривица је мени причао да је он ишао код овога министра културе, филхармоније, Тасовац, је ли тако? Овај, он је ишао код њега у оперу. Два-три мјесеца је тамо Тасовац тражио од њега 
да му свира нешто на гуслама у склопу неке представе коју прави. Мислим да не треба бјежати од тога, али не треба се упустити у то да гусле изгубе онај свој звук и онај њихов начин.

J: Значи, традиција гуслања по вашем мишљењу је јединствена. А оно што се дешава на такмичењима, да ли је то традиција?

M: Ако мислите такмичења, да ли се традиционално одржавају, дуго, или мислите начин гуслања?

J: Мислим, да ли је гуслање заиста усмјерено на очување традиције?

M: Па јесте, посебно сад. Некад је то можда другачије било, кад сам ја почео да се такмичим, ево на примјер, сада уводе...То су увели да морате да пјевате једну епску неримовану пјесму.

J: Кад смо већ код тога, да ли су епске римоване или епске неримоване традиција? Шта је у свему томе традиција, а шта је иновација?

M: По мени је све то традиционално.

J: И римоване и неримоване?

M: И неримоване су ипак нешто епске, римоване су нешто друго.

J: Значи и гусларска традиција има своје фазе и иновације?

M: Па има, али се... Има баш због популаризације, али опет се чува нека традиција. Није то баш сад да је то потпуно. Мислим да се чува традиција.

J: Кад су се тек појавиле те римоване?

М: И то, тај начин наступа у традиционалној ношњи, то неко, опет се ту одржава та традиција, али се ради мало и на популаризацији, на томе да гусле не изумру у овом времену у коме је много тешко да опстану. Никад није теже вријеме по гусле било.

J: Размишљам о томе, када су се тек појавиле римоване пјесме, заправо када се покушао наћи простор 
и за извођење таквих пјесама? Шта мислите како је то изгледало онима који су били поборници традиције? Као светогрђе?

M: Па и дан-данас имате таквих, баш због... и дан-данас имате таквих који те пјесме не сматрају пјесмама. То је нешто што не бисте смјели на гуслама да изводите.

J: Је ли познајете такве? И како они бране тај свој став?

M: Па њихов су аргумент само традиција, традиција и традиција.

J: А традиција су Вукове пјесме?

М: Само Вукове пјесме.

J: Које они уче из књига, је ли тако?

M: Јесте, имају књиге и уче из књига. Постоји још доста пјесама које стари људи знају, па су те пјесме или записане, или оне једноставно имају, једноставно, знају их напамет, и које вам изрецитују и ви можете да пјевате. Постоје људи компетентни, ево ја нисам, да процијене да ли је то пјесма која је народна епска.

J: Хајде да разговарамо мало о статусу гусала у заједници. Кажем заједница, притом мислим на породицу, значи на то окружење. Кад кажете, кад нам дођу гости, када су породична окупљања, када су свадбе, када су, значи, некакви догађаји који одређену заједницу окупљају око неког догађаја... Нису сви мушкарци из одређене породице гуслари, увијек је то неко ко је био талентован, ко је био надарен. Ево ви сте рекли, мој стриц је био гуслар, мој отац није. Зашто стриц јесте, а отац није?

M: Па једноставно, мој отац је један од људи. Ја не познајем човјека да воли гусле више од њега. Он је фасциниран, он их обожава.

J: Али није био извођач?

M: Није, он се трудио да научи, али једноставно није имао талента ни слуха за то. Завршио је и медици- 
ну и све значи, успио је на том неком нивоу образовања и школства, али никад није успио да научи да гусла.

J: Увијек се у породици нађе неки талентовани појединац који је талентован и заинтересован.

М: Па зависи, нађе се увијек, некад имате људе, ја сам упознао доста људи који једноставно... Који су и мене покушавали молити: „Ајде да ме научиш!“. Покушавао сам, али, једноставно, не иде кад неко нема слуха, онда не иде. Тако да, зависи, то зависи од човјека до човјека. Имате и оних који немају талента, труде се, па на крају науче нешто, али то је оно што смо причали малоприје, то некој широкој маси се и не свиђа.

J: А значи, постоје гуслари који су препознати у својој примарној заједници, породици, селу, породичном окружењу. Па су позивани да присуствују одређеним манифестацијама, да ли као гости на свадби, да ли као рођаци или познаници. Значи изван тог окружења, њихов статус у заједници је двојак. Они могу бити експонирани и кроз удружење и на такмичењима, или медијски?

М: Као појединци, као личности. Ево ја сам данас требао да идем горе на манифестацију на Убла. Нисам могао, нешто сам био спријечен, овај, имате једноставно статус гуслара у...

J: Какав је тај статус гуслара, какав је ево конкретно у вашој средини или у поређењу са неким другим, колико имате сазнање и искуство? Шта мислите какав би он требао да буде? Какав јесте и какав би требао да буде?

M: Па овдје у Херцеговини статус гуслара је... Уважен је гуслар, ја мислим да је гуслар уважен. По свом неком искуству знам, гдје год да сам дошао, знају ме сви као гуслара. Учествујем одавно и гуслам, цијене ме људи, цијене ме првенствено због тог што сам гуслар, нико ме не би омаловажавао. Док, имао сам ја 
тежак тај неки период, јер сам ја од четврте године почео. То је неки период кад сам био пубертету, основна и средња школа. Омладина то мало гура у страну, мало се дистанцира од тога. Онда на неке, знате како, кад сте гуслар онда вас сматрају неким много озбиљним, неком ко није за друштво, ко је стармали, па вас знају често зезати, оно што смо причали да више припада сеоском менталитету, ти си сељак. То се превазиђе ако имате велику љубав према томе, и у неком периоду, тог неког одрастања. Касније схвате да у ствари гусле јесу неко наше национално благо, овај, неки национални инструмент. Тако да мислим да у друштву у ком живимо тренутно, гуслар је цијењен, али сигурно да није онолико колико би требао бити цијењен. То што ја мислим јесте овај, што су гусларима. Гуслари немају никакав извор финансија, на примјер, сами се боре да некако могу да оду и на фестивале, често многи од нас сами финансирамо то одлазак на неки фестивал, одлазак на неки јавни наступ, овај нису цијењени у том неком домену, домену финансирања и популаризације. Али мислим да српски народ цијени гуслара као неку личност која његује традицију.

J: Могу да закључим да не постоји нека врста институционалне подршке, мислим на државу, на њена министарства која би то требала подржати?

M: Постоје, али минимална.

$\mathrm{J}:$ Мислите да у медијском простору то није присутно?

M: Не, и много ми је жао због тога, и мислим да то ни мало није фер према, не према гусларима, већ према гуслама.

J: А који музички жанр више подржавају?

M: Комерцијализација, овај ове модерне неке нове пјесме које народ више воли, нешто што... 
J: Говоримо о институционалној подршци, који музички жанр, и коју музичку област испољавања државне институције више промовишу?

М: Па државне институције промовишу, мислим да не промовишу више ништа што је традиционално, мислим да то не добија ни у пола колико заслужује.

J: Добро, живимо у сиромашној држави, али говорим ево рецимо јавни РТС сервис. Шта је ту?

M: На РТС-у имате доста, ја сам видио да има доста народне ове музике, старе изворне, неке музике која нису гусле. Али мислим да, ја не памтим да сам на РТС-у видио некад неки фестивал гуслара који су снимали, ни неку емисију о гуслама. Можда су се некад појавиле гусле у некој причи случајно, али да се баш око гусала позабавила држава и неки јавни сервис, нису. И мислим да је то јако, то је велика грешка. Мислим да гусле то води у пропаст, и мислим да ће због тога да изумру. Неће док има још неко попут мене, млад. То су у задње вријеме, овај врло често да омладина покушава и да се труди да воли гусле, и да оће да науче. Мислим да то неће брзо изумријети, али настави ли се овако, гусле неће више постојати.

J: Још ме интересује, то је једна и велика тема, али ако се нисте уморили и ако сте расположени да наставимо разговор, интересује ме овај текстуални облик, односно сам садржај пјесама које се изводе. Да мало разговарамо о томе? Рекли сте ми да постоји класични корпус, дакле из Вукове збирке, као оно што је познато, и препознато, и несумњиво у погледу вриједности. Је ли тако? Значи, то је класични репертоар, има неупитиву вриједност. А када је у питању ова друга димензија гусларског репертоара, како се то заправо стиче вриједност, односно како се обликују текстови који би могли бити прихваћени? Да ли је гуслар усмјерен на себе 
и своју потребу да неку тему обради, или је условљен очекивањем, интересовањем и укусом публике?

М: Па, и једно и друго.

J: Јесте ли сада рекли да гуслар може да да један максимално лични печат својој изведби, а да се то уопште не допадне публици, значи он је као гуслар потпуно промашена инвестиција, јер гуслар без публике, односно гуслар који гусла за своју душу је једна апстрактна фигура која не функционише?

М: Као гуслар није жив, да.

J: Као гуслар није жив, е лијепо сте то рекли. Значи, он апсолутно зависи од публике и њене реакције. Како се ствара пјесничка прича, да је тако назовем, у том компромису публике и ствараоца? Које су то, прво, теме, и онда, који су то начини обраде, како се те теме обрађују?

M: Па, то су теме... причали смо малоприје о томе. Теме су, значи, историјске, све су то историјске теме. Неке су, значи, наше даље историје, неке наше ближе историје. Те новокомпоноване пјесме, римоване...

J: То је, значи, савремени поглед на даљу историју или парафраза, односно препричавање, односно преобликовање класичног корпуса Вуковог?

M: Јесте. На примјер, Косовска битка. Радован Требишки је писао по Вуковом корпусу, али је то мало стилизовано, накићено. Римоване пјесме по мени су много кићеније и љепше за слушати. И читати. Мало су јасније, некако. Али ако ја сад сједим у друштву озбиљнијих људи, људи којима је епска поезија блиска и који више њу цијене, ја ћу да пјевам пред њима Вукову, јер они воле то да чују. Ако сједим у друштву у ком су људи који онако воле гусле, али су више тог савременијег типа, ја ћу им пјевати ову новокомпоновану.

J: Значи, постоје љубитељи гусала који су, да кажем, необразовани у погледу класичног Вуковог кор- 
пуса, који то не познају, а воле гусле? Они немају могућност порећења?

М: Па опет зависи од, све зависи од човјека до човјека.

J: Колико је уопште познавање Вуковог корпуса присутно изван гусларских кругова, то је оно што ме много интересује?

М: Јако слабо, И то ко зна, знају старији људи. Људи који су једноставно навикли да, имали су вјероватно оца, мајку који су их учили да то читају. И знају. Ове новије генерације слабо знају, они никако гусларске не знају. Једино мало нешто кроз школу, то што се у школи неке пјесме уче, на примјер „Стари Вујадин“, мислим да има и „Предраг и Ненад“.

J: Која је ваша омиљена пјесма из тог класичног корпуса?

М: Из Вукове збирке? Па, ја волим „Предраг и Ненад“. То је прва пјесма коју сам научио. Знам овако још доста пјесама, на примјер „Ропство Јанковић Стојана“, „Бој на Мишару“. Знам доста пјесама које онако...

J: Које публика воли, из тог корпуса?

М: Па воли више те пјесме које су... По мом мишљењу, имају неке пјесме Вукове које су занимљивије, нагињу ка неком модернијем стилу.

J: Које су то, на примјер?

М: Па, „Предраг и Ненад“ имају неку причу и текст који је доста разумљив. „Косовска битка“ исто, много је фина, „Бој на Мишару“. То је отпјевано значи неко дешавање, онако.

J: Смијем ли ја да закључим? Кратке су. „Стари Вујадин“, „Орање Краљевића Марка“... Значи, то су неке краће пјесме које публика може да испрати, за које може да издвоји пажњу. А шта из Вуковог корпуса не иде?

M: Па не знам, те и не свирам. Кажем Вам, то су те неке пјесме које се врте, и које су мени заокупиле 
пажњу. Читао сам још неке, али једноставно, нешто што вас не интересује, то и не запамтите.

J: А шта данашња публика заправо очекује, које теме?

M: Данашња публика углавном очекује новије теме, из новије историје.

J: А шта је новија историја?

M: Па задњих можда сто година, о Првом, о Другом свјетском рату. У посљедње вријеме највише воле ове о грађанском рату. Али те пјесме још немају историјски неки печат... Још историја није утврдила шта и како, али народ се некако поистовјећује, блиска им је та историја, и то више доживљавају. Неком човјеку од четрдесет-педесет година деда био у четницима. И он воли да чује пјесму о Дражи Михајловићу, неком је тамо ратовао са Ратком Младићем, он то кад чује њему је то неки, не знам ни ја, израз српства. И пуно му је срце. Неком је опет био деда у гарди краља Петра, па воли то да чује. Углавном, тема која сваког заокупи је Косовска битка, то је можда највећа, историјска, нешто што је онако оставило дубок траг у српској историји, у српском народу. Косовска битка је највећи догађај што се десио у српској историји, по мени.

J:Добро, а осим историјских тема?

М: И ту људи налазе ове, поистовјећују се са... На примјер, доста пјесама поистовјећују Ратка Младића са Обилићем, Дражу Михајловића. Издајнике поистовјећују са Вуком Бранковићем.

J: А изван историјских тема, да ли се обрађују неке друге? На примјер?

М: Да, па имате једноставно, шта знам, што није везано уско за те грађанске ратове, борбе и битке. Имате на примјер, ја сам овај гуслао на промоцији једне пјесме... јој како се зове? „Несуђена љубав“ се зове пјесма... 
за догађаје који нису везани за историју. На примјер та пјесма је написана у осмерцу. Заборавио сам рећи да је на такмичењу обавезно десетерачки стил.

\section{J: Зашто?}

М: Па не знам, то су узели као изворни стил.

J: А осмерачке су мање присутне, ајде да кажемо у традицији?

М: Мислим да су мање присутне.

$\mathrm{J}:$ Колико ви знате осмерачких?

М: Ја знам три, четири пјесме у осмерачком стилу, мислим да су епске пјесме писане у десетерачком стилу.

$\mathrm{J}:$ А којом се још тематиком баве осмерачке?

М: Па ето краљ Никола кад је удавао кћерку.

J: Како се зове та пјесма?

M: „Јелена“. Имате и пјесму „Јелена од Босне“, онда имате да нису историјске.

J: Знате ли неку исторјску осмерачку?

M: Има, „Спомен на Тари ријеци“. Не могу сад да се сјетим свих пјесама, али доста пјесама знам, а не знам им називе.

J: Која је разлика, по Вама, између десетерачких и осмерачких? У смислу извођења? И популарности?

М: Много је лакше пјевати осмерачке пјесме, некако су ритмичније, и људи их више воле.

J: А зашто онда на тим фестивалима није присутна више осмерачка епика?

M: Ја мислим да је некад било, али су увели само десетерачки стил.

$\mathrm{J}:$ Да ли се игра икада уз гусле? Да ли постоји неки облик покрета или праћења покретом? Барем кад су ове осмерачке у питању?

M: Не, не, ако се већ пјевају те пјесме... Зависи, имате заједничке пјесме које се пјевају, ганге, и тако то. Можда народ и игра уз те пјесме, али уз гусле се не игра. 
J: Барем оро или неко коло?

M: Па ја, на примјер, знам да свирам, али то је опет модерније.

J: Говорим баш о овим осмерачким, јер су ритмичније. То што су ритмичније можда налаже да...?

$\mathrm{M}: \mathrm{He}$, не игра се никад. Нисам ни чуо ни видио да је неко играо уз те пјесме. Углавном су, много су, лакше их слушаоци слушају јер се брже пјевају.

J: Добро, а да ли те савремене новокомпоноване, да ли се често у осмерцу склапају?

M: Пишу пјесници осмерачке пјесме доста, али овај, и те новокомпоноване, нема никаквог покрета ни играња.

J: Добро, добро, то сам разумјела. Значи, те пропозиције на такмичењима налажу искључиво десетерачке?

М: Да.

J: Добро, значи тематика њихова може бити историјска, и може бити...? Како бисте Ви назвали ову тематику у пјесмама, што сте рекли, „Јелена“, „Јелена од Босне“? Који бисте назив дали том типу пјесама?

M: Шта знам, то су по мени новокомпоноване пјесме. „Јелена“... „Краљ Никола“ није, али то су опет пјесме које нису јуначке, историјске, и нису отпјеване битке, бојеви.

J: Нема неки посебан назив за ту врсту?

$\mathrm{M}:$ Не, да ја знам нема.

J: Да, њих често изводите у женској публици?

М: Да, да, ево на примјер „Стојан и Љиљана“, она је десетерачка.

J: Добро...

М: „Погибија попа Мила Јововића“, можда најпопуларнија пјесма у народу, осмерачка. Ту је пјесму обрадио и Рамбо Амадеус у неком свом стилу. Онда имате тих познатих пјесама што људи воле, „Суђење Шћепану Радојевићу“, то је новокомпонована пјесма. 
J:. А шта је са оним уласком стварних личности, савремених и живих људи у пјесму? Шта је са тим?

М: Па то су, то је јако ријетко да гуслари пјевају те пјесме. О људима који су стварни, који данас живе. Мислим, изузетак су велики Радован Караџић и Ратко Младић. Они су значи стварно, посебно док још нису били ухапшени. То су биле пјесме које су биле ненормално популарне. Једноставно, они су живјели са тим пјесмама. И обожавали су то.

J: А шта је са оним пјесмама које су, хајде да кажем, изван јавне сцене, изван историјског круга? Шта је са оним пјесмама о, рецимо, саобраћајним несрећама, прерано погинулим, или... Не знам?

М: Има их, постоје те пјесме.

J: Да кажем, нарученим или спонтано створеним које нису од неког великог значаја за неку ширу заједницу, већ за породицу?

М: Па зависи, тих пјесама има доста, јер данас се јако велики број људи бави писањем пјесама. Једноставно наручите нешто, баш што ви кажете, о саобраћајним несрећама. По мени је то јако тешка тематика, ја не изводим такве пјесме. Али гуслари, наравно ако су пријатељи са том неком породицом, ако их та породица позове, свиђа им се њихов стил или начин на коју ће он ту пјесму да отпјева, онда га позове и плати му одређени износ. Те пјесме... Ријетко ћете наћи те ЦД-ове у продаји. То су ЦД-ови који се чувају за себе. Чувају успомену на неку личност.

J: А шта је потребно пјесми да би добила ширу популарност?

М: Па, ево кажем Вам. Те историјске личности, Радован Караџић и Ратко Младић. Не можемо за њих рећи да су историја, они су још живи. Али они су учествовали на неки начин у животима свих нас. Те неке, 
кажем Вам, историјске личности попут Драже Михајловића, краља Петра, Александра, не знам ни ја. Неко воли то, обожава то да чује, јер је у породици вјероватно имао додирних тачака са њиховим постојањем. И то је, некако, нешто што одржава ту пјесму, чини интересантном и одржава је у народу. На примјер, ја сад дођем, и он ми каже: „Ајде, молим те нешто о Радовану Караџићу, знаш ли нешто о Ратку, Дражи?“"И тако.

J: Опет ћу се вратити на такмичења, то ми је веома интересантно. Да ли гуслари имају некакве своје мале ритуале, свако понаособ, како се припремају за сцену?

М: Па могу вам ја на мом личном примјеру. Кад се спремам за фестивал, значи, спремам се неких мјесец дана. Некад мање, некад више. Гуслам углавном сваки дан по неколико пута те пјесме које сам пријавио, вјежбам их да би могао имати капацитет плућа, вјежбам како ћу отпјевати који стих, небитно. Овај, што се тиче ритуала, има, на примјер ови стари гуслари прије сваког наступа они као морају чашицу ракије да попију. То им је нешто као за глас, знате, онда многи од њих носе фен, па грију кожу доље на гуслама да она буде јако затегнута и то. Онда доста гуслара, мислим деведесет посто гуслара на дан наступа пред такмичење спава поподне, да буде што одморнији, не једу да би једноставно имали капацитет плућа, да би могли да дишу нормално и пјевају. Иначе, гуслати и пјевати је јако тешко. Овај, онда, шта знам ја, за грло, на примјер, не пијем хладно, газирано, трудим се да избјегавам буку, галаму, негдје гдје сам у граду да не би гасно причао, напрезао гласне жице. И тако. Не знам, има доста тих ритуала, ево баш сад, имам тај неки... кад мало осјетим да ме мало боли грло, узмем кашичицу меда, ставим испод језика да се то једноставно истопи. 
J: А да ли постоје некакве амајлије или предмети?

M: Па ријетко ко, на примјер имате гусларе који онако, ја сам гледао неколико пута, имате на примјер ставе овај револвер стари, као, закачи за пас. Или носи, или на гуслама има закачен крстић, или тако нешто. Носе неки грб, на примјер, двоглавог орла, али то нису нека... није неко сујевјерје и вјеровање да ће му то донијети нешто. Једноставно, начин неки, израз гуслара.

J: А да се још вратимо на ону тему, негдје смо само брзо прошли преко ње. Тиче се израде гусала, односно њиховог украшавања. Па смо негдје констатовали да је заштитни знак радионице чувеног мајстора из Требиња, била сцена Светог Георгија?

М: Није он из Требиња, он је из Црне Горе.

J: Да ли постоје још некакви типови украшавања? И да ли постоји одређено везивање за неки крај или неку гусларску традицију?

M: Па, нема неког везивања за неки крај и традицију. Нама, углавном, ти мајстори праве то што им се наручи, ако могу да направе.

J: А шта се најчешће наручује?

M: Најчешће се на задњем дијелу, доље на карлици, овај, или оно што у музици зову нека као резонаторска кутија доле. На задњем дијелу углавном се, углавном мајстори оцртавају Острог, слава му и милост. Имате затим на држалу, на неким као плочама оцртавају Његоша, Карађорђа, те неке историјске личности: Црногорци из њихове историје, Србијанци углавном Карађорђа, ево ја... Имао сам доста гусала. Моје прве су биле горе са украсом двоглавог орла, грб двоглавог орла, па сам имао гусле са козјом главом, па са орлом, па опет са орлом.

J: А ваш деда са својом фотографијом?

M: Да. 
J: А ова козја глава, је ли има неку симболику?

M: Па не знам, стварно не знам.

J: Зашто имамо козју главу на гуслама? Змија је често?

М: Да, да, има и змија. Ја сам гледао доста гусала да гудало направе са изгледом змије, читаво тијело змије. Имате змију, имате Свети Георгије, ма имате свакаквих сам ја изгледа гледао. Мислим да нема неко правило ни шаблон, углавном праве шта им се наручи. Ја сам гледао, на примјер, гусле са ланцима, све около ланци.

J: Добро, добро. Добро, јесмо ли нешто заборавили да пређемо, а што по вашем мишљењу је значајно за тему нашег разговора? Јесам ли заборавила нешто да вас питам?

M: Па ја сам вам рекао све углавном, али овај, можда једина тема на којој бих ја много радио, то је да се ради на популаризацији гусала. И на оно, што сам вам причао, о подршци саме државе, подршци институција, да се одрже гусле. И једноставно, да то може да заживи у народу.

\section{Литература:}

Делић, Лидија. „Јуначка епика као Living Human Treasure“. Лицеум, год. XXIII, 18 (2017): 47-59.

Ђорђевић Белић, Смиљана. Постболклорна епска хроника. Жанр на гранищи и гранище жанра, Београд: Чигоја штампа, 2016.

Кнежевић, Саша. Вишюићев пјеснички споменик револуцији. Пале: СПКД „Просвјета“, 2012.

Краус, Ентони. „Конвенција о заштити нематеријалног културног насљеђа из 2003. године: изазови и перспективе“. Нематеријално културно наслеђе Србије 1, Београд: Ми- 
нистарство културе, информисања и информационог друштва - Центар за заштиту Нематеријалног културног наслеђа, 2011. 10-14.

Медар Тањга, Ирена, Јеленка Пандуревић и Драгица Панић Кашански. Нематеријално културно настеђе. Теоријски, методолошки и административни аспекти. Бања Лука: Филолошки факултет, 2017.

Пандуревић, Јеленка. „Други живот друге књиге. Усмена рецепција Вукове збирке данас“. Н. Милошевић-Ђорђевић (ур.). Вук Стефбановић Караџић (1787-1864-2014). Београд: САНУ, 2015. 327-347.

Tsitsishvili, Nino „Nacionalne ideologije u eri globalnih fuzija: gruzijsko polifono pjevanje kao UNESCO-ovo remek-djelo nematerijalne baštine“. M. Hameršak, I. Pleše i A. M. Vukušić (ur.). Proizvodnja baštine: kritičke studije o nematerijalnoj kulturi. Zagreb: Institut za etnologiju i folkloristiku, 2013. 204-232.

Prof. Jelenka Pandurević, PhD

University of Banja Luka

Faculty of Philology

\section{VIŠNJIĆ'S EPIC PARADIGM AS INTANGIBLE CULTURAL HERITAGE}

In this paper, consider the reasons, possibilities and limitations to understand the heroic epic and a singing with a gusle in accordance with the 2003 UNESCO Convention for the Safeguarding of the Intangible Cultural Heritage as a local and national tradition. Actuality of the topic is related to the fact that this element, present in the registers of the Republic of Serbia and the Republic of Srpska, necessarily perceived as a "living" tradition shared by communities and individuals as an expression of their cultural heritage, maintaining, according to UNESCO's definition, a "sense of identity and continuity". Višnjić's epic par- 
adigm is the term used in this paper to indicate not so much the sporadic inadmissibility of administrative solutions that insist on the care and preservation of cultural heritage exclusively within modern state borders, as for the unused possibilities in terms of joint nominations for the List of Representative Intangible Cultural Heritage of Humanity, what are the models that UNESCO actually promotes and supports.

Key words: Filip Višnjić, heroic epic, a singing with a gusle, intangible cultural heritage, UNESCO, nominations of elements. 